\title{
NOTES ON THE HISTORY OF GOITRE IN SWEDEN*
}

(Remarks on its Significance for the Aetiology of the Disorder)

by

\section{ISIDOR GREENWALD}

IT is the purpose of this paper to show that goitre was probably not known and was, almost certainly, not endemic anywhere in Sweden before the nineteenth century, and to give a reasonable explanation for its initial appearance in Falun and vicinity and its subsequent spread.

The history of goitre in Sweden has already been considered by Höjer, ${ }^{1}$ who concluded that the disease was present before the nineteenth century. His evidence and the reasons for rejecting his conclusion will be considered later.

As Höjer recognized, there is no native Swedish word for goitre. He quoted from Björnståhl ${ }^{2}$ a long passage dealing with goitres seen in Savoy and in Italy in I 773. I will repeat only a small portion (Vol. 2, p. 25).

'Hela denna vägen ifrån Mont-Cenis finnes en myckenhet menniskor af båda könen med stora växter på halsen, framantil och på sidforna, som kallas härstädes les guâtres, och på Italienska scrofe: vi äre så lyckelige i Sverige, att vi icke hafva namn på dem så mycket jag vet, så framt man icke vill kalla dem flenbo eller flenhus.' [On the whole way from Mount-Genis I saw many people of both sexes with large goitres on the front and side of the neck. These are here called 'guâtres' and in Italy 'scrofe'. We are fortunate in Sweden that we do not have a name for this, so far as I know, unless one would call it 'flenbo' or 'flenhus'.]

A people is not fortunate merely in that it does not have a word for a disease; it is fortunate that it does not have the disorder.

In fact, Björnståhl went on to compare Savoy with Dalecarlia and to note the similarity in aspect, but with the significant difference that goitre was not present in Dalecarlia. As Höjer wrote, Björnståhl knew Dalecarlia well. Consequently, his statement must be accepted as authoritative.

At about the same time as Björnståhl, Palmstedt ${ }^{3}$ also saw goitres in Savoy and wrote in his journal: 'Mäst alle Quinfolk och en stor del karlar hafwa Flenhus pa högra sedan am halsen under hakan.' [Nearly all the women and most of the men have 'Flenhus' on the neck under the chin.] The editor (Martin Olsson) added a footnote, 'Flenhus eller aterom, ett slags svulst under huden. Struma.' [Flenhus, or atheroma, a kind of tumour under the skin. Struma.]

Neither Björnståhl nor Palmstedt were physicians, and could not have been expected to know a more specific term for goitre. They used the word which,

* This research was aided by a grant from the National Institutes of Health. 


\section{Notes on the History of Goitre in Sweden}

in their vocabulary, applied to tumours resembling goitres. Björnståhl, at least, was not at all certain that he was correct in his choice.

I have found no other use of the word 'flenbo' but 'flenhus' was in use before I763. Several examples dating from the eighteenth century are given in the dictionary of the Swedish Academy 4 but none of these gives any clear indication that goitre was meant although it is possible that cystic goitres might have been included in what was certainly a miscellaneous group. Haartman ${ }^{5}$ used 'Hälsesvulst' [neck tumour] as a synonym for 'flenhus'. 'Hälsesvulst' was also used by Acrel $^{6}$ to denote some cystic tumours that he had seen. He reported two instances in which he opened the cyst. In the introduction to his book, he showed that he was well acquainted with other European medical literature, as indeed Haartman also was. Significantly, neither Acrel nor Haartman used 'bronchocele', 'struma' or 'botium'. Nor did the German translator' of Acrel's book use the term 'Kropf.' He called the tumours 'Weiche Hülsen oder Honiggeschwülste am Halse'.

The available dictionaries giving the equivalents of Swedish words in other European languages give no indication that either 'flenhus' or 'hälsesvulst' meant goitre. Ihre ${ }^{8}$ wrote, 'FlenHus dicitur extumescentia quae apostematis instar in facie aliave corporis exoritur'. Sahlstedt ${ }^{9}$ gave the Latin equivalent of 'flenhus' as 'ganglion, tumor', and Widegren ${ }^{10}$ gave the English equivalent also as 'ganglion'. Weste ${ }^{11}$ translated 'flenhus' into French as 'ganglion, loupe'. Equally significant is the translation of the French 'goitre' as 'svampaktig halsväxt el knöl, som i synnerhet är allmän hos folket på Alpiska och Pyrenerska bergen'. [A spongy growth or knob in the neck, particularly common among the people of the Alps and Pyrenees.] ${ }^{11}$ Apparently, the Swedish compilers of this dictionary at the end of the eighteenth century knew of no Swedish equivalent for 'goitre'.

Early in the nineteenth century, Bladh visited South America and wrote two books ${ }^{12,13}$ concerning his experiences there. In the first of these we find (p. 299) regarding Mendoza, Argentina, ‘. . . den skulle äfven äga ett sundt klimat, om icke el coto* grasserade värre här, . . * En slags svullnad, som fäster sig i halsen.' (Se vidare härsom, Republiken Chile, page 206). [The climate is good, except for the ravages of el coto,* ...*a kind of swelling found in the neck. (See also Republiken Chile, page 206).] Referring to that we find: 'Oektadt klimatet öfverhufvud är sundt, existear här likväl en partiel åkomma, hvilken visar sig på hallsen medelst en svullnad, som i början är liten, mer småningom växer till en oformlik storlek. Denna sorts karbunkel eller flenhus ... hvilken Chilernen kalla Coto. ... [Although the climate is, on the whole, good, there is common a swelling on the neck which begins small but grows to very great size. This kind of carbuncle or 'flenhus' the Chileans call coto.]

It seems quite clear that Bladh did not know of goitre in Sweden, even as late as 1837 and 1839 when he wrote his books in Stockholm.

I have found no other reports by Swedish travellers of their visits, in the eighteenth and early nineteenth centuries, to foreign countries in which goitre 


\section{Isidor Greenwald}

was common. There are, however, a number of accounts by Swedish, English, French, German and Dutch visitors to Dalecarlia, and particularly to Falun. Some of these, by Per Kalm ${ }^{14}$, Hülphers ${ }^{15,16}$ and Hårleman ${ }^{17}$ have already been discussed by Höjer. ${ }^{1}$

I have examined all four of these and can concur in Höjer's opinion that the authors described the diseases seen or reported to them in such detail as to make it certain that goitre, if at all common, would have been mentioned. Per Kalm's description of Dalecarlia and Hülphers' of Falun were particularly detailed. Hülphers' statements regarding diseases were repeatedly quoted in an official discussion of the medical topography of Sweden in $1851 .{ }^{18}$

However, in spite of these observations, Höjer remained of the opinion that goitre was present in Sweden in the eighteenth century. $\mathrm{He}$ found it difficult to understand that Trafvenfelt should have published Berggren's report on goitre in Falun in $1816^{19}$ without comment if goitre were really a new phenomenon in Sweden. We cannot, at this late date, know Trafvenfelt's reasons. Possibly, the occurrence of goitre in Falun and vicinity was known to Trafvenfelt and his circle, even though not previously recorded. However, as we shall show later, goitre was almost certainly not present in 1768 and, probably, not until considerably later.

Höjer also believed that three portraits by Pasch, the younger (1 733-1805) showed the presence of goitre. These portraits and many others by the same artist have been published in black and white by Strömbom. ${ }^{20} \mathrm{I}$ have examined all of these and do not find that any of them do more than suggest the possibility of an enlarged thyroid. It is, of course, impossible to state that none of the three women mentioned by Höjer did not have enlarged thyroids, but it is equally impossible to state that they had. In any event, the existence of these pictures seems a slender thread upon which to hang the hypothesis that goitre was endemic in Sweden at that time.

There has been published a report of the Collegium Medicum to the RiksDag of $1769 .{ }^{21}$ This includes reports by physicians from many parts of Sweden regarding conditions for 1765 to 1768 , inclusive. I have found no references to goitre in any of these and certainly none in the 44 pages by Blom on the mountainous regions of Dalecarlia and Kopparberg nor in the eleven pages of Engström's report on Falun.

We now turn to the reports of other visitors to Falun. In 1765 , Drevon ${ }^{22}$ travelled through Sweden, visited Falun and gave a quite lengthy description of the mines. He made no mention of goitre there, or elsewhere. Of the Swedish people, in general, he wrote: 'They are good-natured and honest beyond example and are very robust and healthy, especially in Dalecarlia.' Linnerholm ${ }^{23}$ visited Falun in 1787 and again in 1807 . He made no mention of goitre at either time. On his first visit, he commented on the head-dress of the women. Clarke ${ }^{24}$ and Schmidt ${ }^{25}$ in 1799 and $\mathbf{E c k}^{26}$ in 1801 all travelled extensively in Sweden, spent considerable time in and about Falun and Dalecarlia, commented on the appearance of the women, but wrote nothing about goitre. 


\section{Notes on the History of Goitre in Sweden}

Even more noteworthy is the failure of Küttner (1 798-9) 27 who shortly afterwards dwelt at length upon the goitres seen in Switzerland, Styria, Carinthia, Savoy and parts of Italy, to note their presence in and about Falun.

It seems quite evident that the disease was not frequent and probably not present until the nineteenth century.

The first report of goitre ('Bronchocele') in Sweden that I have found was in 1815 (Berggren, ${ }^{19}$ ). It dealt with the prevalence of the disorder in Falun. Not more than twenty years later, Hartmann*28 wrote 'Strupsvulst. Struma. Denna sjukdom förkommer lyckligtigwis icke ofta i Swerige, men bör dock nämnas. ... Är endemisk i låga och fvktiga trakter. ...' [Strupsvulst, Struma. This disease fortunately does not occur frequently in Sweden, but it should be mentioned. ... It is endemic in low and moist areas. ... . He gave no instances of such endemicity.

The word 'strupsvulst' means, literally, 'throat tumour'. I have not found it in any of the several dictionaries consulted. It is listed in a Swedish encyclopedia. ${ }^{29}$ The reader is referred to the article on 'Strup' (larynx). That has no mention of goitre, the tumours discussed being those of the larynx, chiefly polyps and carcinoma.

'Struma' as meaning goitre seems to have been first employed, in Sweden, by Hartmann. All subsequent writers seem to have followed his example. However, 'struma' originally meant 'scrofula' and it was so used in Sweden as late as I 747. 'Struma =Halsbold, wext. tumor in quo est pus', (Schenberg, ${ }^{30}$ ). Hartmann used 'skrofler' for 'scrofula' and that seems to have been the custom ever since.

In 1853 there appeared a lengthy report on medical activities in Sweden, as of $185 \mathrm{I} .{ }^{18} \mathrm{It}$ included a discussion of the diseases prevalent in each district by the physician in charge thereof. Goitre was said to be endemic in and about Falun. Elmin, the provincial physician at Herjeådalen, wrote, 'strumatösa och scrofulösa svulster och sinnessjukdomar skola ej heller vara sällsynta.' [Neither strumous nor scrofulous tumours nor mental diseases are infrequent.] I have found no other mention of goitre in these accounts nor did Berg ${ }^{31}$ include any other in his account of the medical topography of Sweden, which was based on this report. However, Hus ${ }^{32}$ stated that goitre was present in two parishes adjoining Falun and in Gefle. The report ${ }^{18}$ included a great deal of information regarding the character and costs of medical care. The various 'baths' were mentioned, together with the diseases for which they were visited. 'Skrofler' was included but neither 'struma' nor 'strupsvulst'.

The reports of the Sundhets-Collegium from 186 I to 1878 and of the Kungliga Medicinal Styrelsen from 1879 to 1920 , after which such information was no longer included, show an increasing occurrence and spread of 'struma'. In I86I it was noted as frequent only at Falun and in Elfdalen and as 'icke sa sällan' [not rare] in northern Jemtland. In the following year Leffler reported its presence in Leksand. Physicians were asked to send in reports of goitre in their localities. Down to 1868 , the last year in which information so obtained

\footnotetext{
* Not to be confused with Haartman.
} 


\section{Isidor Greenwald}

was published in these reports, most of the cases were from Falun and nearly all of the others from the districts of Kopparberg and Gefle. (Statistika CentralByran. ${ }^{33}$ )

There were also statements from the various 'baths' giving the number of persons attending and the disorders for which they sought relief. There were varying small numbers of persons with 'strupsvulst', which condition was also reported from various hospitals, but their number was always small. Whether or not any of these were goitre cannot be ascertained. However, in $187 \mathrm{I}$, one case of 'strupsvulst' (struma) was reported from the Allmänna Garnisonssjukhuset. This was the first use of the word 'struma' in these reports from any hospital.

The number and kind of operations at the various hospitals were first included in these reports in 1883 . There were nine for 'struma', with one death. From that time to 1920 , after which such information was no longer given in these reports, there was a steady increase in the number of such operations.

Basedow's disease seems to have made its first appearance in these reports in 1897 , after which there was a steady increase in the number reported down to the last year ( 1920 ) for which such figures were given. However, the disorder had been recognized at Uppsala before 187 I. In two numbers of the Uppsala läkareförenings förhandlingar in 1871 and 1873 , Glas ${ }^{34}$ reported thirteen cases of Basedow's disease. Most of these were from Uppsala and vicinity. The condition in one of these patients had existed for as much as seventeen years. This was in a man originally from Göteborg län, but who lived later in Gefle and in Germany. It was not stated where he was living when the disorder was first noticed.

Stockholm seems to have been quite free from goitre for many years after it had been reported from Falun and from other places. 'Struma' does not appear in the list of diseases treated at the Seraphimer-Lazarett from August 1839 to December 1840 (Hus, ${ }^{35},{ }^{36}$ ). The first mention of goitre at that hospital that I have found is that of a cystic goitre treated by puncture and injection of iodine in 1867 ( $v$. Döbeln, ${ }^{37}$ ). There was no other goitre listed as having been treated among $\mathrm{I}, 009$ patients in the surgical division in that year and there was none at all among the 1,424 patients in the medical division (von Friesen $^{38}$ ).

The first operations in Sweden for the removal of a goitre seem to have been performed by Rossander ${ }^{39,40}$ in Stockholm in 1871 and 1874 . The second patient came from Dalecarlia. In 1878 , Lindh ${ }^{41}$ at Halmstad, removed a goitre from a woman from Vessige (Halland).

Data for the number of operations for goitre at four different hospitals in five different years between 1897 and 1936 were published by Key ${ }^{42}$ and copied from him by Kock. ${ }^{43}$ I have calculated the ratios of these to the numbers of patients in the surgical divisions of the various hospitals. As may be seen from Table I the number of operations upon the thyroid and the ratio of this to the total number of patients in surgery rose between 1897 and 1926 but fell slightly in 1936 . 


\section{Notes on the History of Goitre in Sweden}

TABLE I

Number of operations for goitre and ratio of this to the number of 'Patients' in the surgical divisions of the hospitals

\begin{tabular}{|c|c|c|c|c|c|c|c|c|}
\hline \multirow{3}{*}{$\begin{array}{l}\text { Year } \\
\text { Hospital } \\
\text { Akademiske sjukhuset Uppsala }\end{array}$} & \multicolumn{2}{|c|}{$\begin{array}{c}1897 \\
\text { No. } \%\end{array}$} & \multicolumn{2}{|c|}{$\begin{array}{c}1906 \\
\text { No. } \%\end{array}$} & \multirow[t]{2}{*}{$\begin{array}{c}\text { rgI6 } \\
\text { No. \% }\end{array}$} & \multirow{2}{*}{\multicolumn{2}{|c|}{$\begin{array}{c}1926 \\
\text { No. \% }\end{array}$}} & \multirow[t]{2}{*}{$\begin{array}{c}1936 \\
\text { No. \% }\end{array}$} \\
\hline & & & & & & & & \\
\hline & $\mathbf{I}$ & $\mathbf{I}$ & 3 & 2 & 2212 & 22 & 7 & $42 \quad 13$ \\
\hline Serafimer-lazarett, Stockholm & 10 & 6 & 26 & 9 & $48 \quad 17$ & 97 & 35 & 5314 \\
\hline Kirurgiska kliniken, Lund & $\mathbf{I}$ & $\mathbf{I}$ & 10 & 6 & 3915 & 53 & 16 & 8820 \\
\hline Maria sjukhus & 2 & 2 & 4 & 3 & 1610 & 45 & 16 & 21 \\
\hline Total & 14 & 3 & 43 & 6 & $125 \quad 14$ & 217 & 18 & 204 \\
\hline
\end{tabular}

Since that time there may have been another increase. In a footnote, Frid and Wijnbladh ${ }^{44}$ stated that from 1948 to 1955 there were 2,85 I cases of goitre (an average of $35^{6}$ per year) treated by surgery, at St. Görans Hospital alone. How many there were in other hospitals is not known to me. Part of this change was probably due to the increasing skill of surgeons and to the more general willingness of patients to accept operation, but it would seem, also, that there may have been a real increase in the number of persons with the disorder, particularly since no account has been taken of the patients who may have been treated by radiation or with anti-thyroid drugs.

Books on household, or domestic medicine, confirm the comparative rarity of goitre during most of the nineteenth century. While Hartmann ${ }^{28}$ had noted the presence of goitre at least as early as 1835 , there were three other authors (Wistrand; ${ }^{45}$ Ruppricht; ${ }^{46}$ Melander $^{47}$ ), who published in 1864, 1865 and 1867, respectively, and who made no mention of this disorder. However, Hallin, who twenty years earlier ${ }^{48}$ had given the first detailed account of goitre anywhere in Sweden, did include both simple goitre and Basedow's disease in his book in 1885. ${ }^{49}$ The former was said to be present in Falun, Gefleborg and Jemtland. In the city of Falun, one per cent of the males and eleven per cent of the females were said to be affected.

In 189 I Nauman ${ }^{50}$ indicated a somewhat wider distribution and, only two years later, Söderbaum ${ }^{51}$ showed that the disorder was no longer most common in Falun, but in Gefle.

In England, goitre was once known as 'Derbyshire neck' because it first became common in Derbyshire. Similarly, according to Söderbaum, goitre was, in I893, known as 'Faluknolen'. Because it was then more common in Gefle, he suggested that it might, more appropriately, be called 'Gefleknölen'.

Since I893 goitre has spread over most of Sweden to such an extent that in I93 I Höjer ${ }^{52}$ concluded that about eighteen per cent of the entire population had visible goitre. It was noteworthy that both Falun and Gefle had lost their sad pre-eminence. In 1929, of the twenty-year-old men called for military 


\section{Isidor Greenwald}

service in Falun and Gefle, only 7 and I4 per cent, respectively, had goitre. (Including the rural districts, the values were io and 20 per cent, respectively.) In one district (Ockerham) the figure was 40 per cent and the average for the entire country was 4.8 per cent, not much lower than in Falun.

Why should goitre have appeared first at Falun and why should it not have been reported in $1767-8^{21}$ but in $1815^{219}$. An examination of the history of the region is rewarding. Hildebrand ${ }^{53}$ in his Falu Stads Historia ${ }_{1} 641-1687$, devoted fifteen pages to 'Lakare, Kirurger, Kvacksalvare och Apothekare' without mentioning goitre. He stated that Stalhoff, a Danish physician, left a list of diseases common in Falun at that time. Through the kindness of Gusfal Holmgren, Keeper of Manuscripts at the Universitetsbiblioteket, Uppsala, I have a copy of that list. There are mentioned epilepsy, apoplexy, pulmonary diseases, cataract, icterus, scurvy and several other disorders but not goitre. There can scarcely be any question but that goitre was not present, certainly not common, at that time.

According to Lindroth ${ }^{54}$, the engineer, Christoph Polhem, who did so much to develop the mines at Falun, visited the Harz in Germany in 1707 and brought back two Germans who spent two years in Falun. Subsequently, three other Germans came to Falun to work with Polhem for periods, the length of which was not stated. It is an interesting possibility that these Germans, from a district in which goitre was prevalent, should have introduced goitre into Sweden.

The writer ${ }^{55}$ has shown previously that the first known appearance of goitre in Derbyshire, England, followed by only a few years the importation of two Italians from Piedmont, a district notorious for its goitres. Similarly, in western Pennsylvania and eastern Ohio, the Delaware Indians seem not to have known goitre until after the Moravian missionaries came among them. In the late eighteenth century, the Delaware word for goitre was 'Knop', which is certainly not Indian, but obviously is related to the German 'Kropf'. ${ }^{56}$

In many other countries, indeed, in most of the world, goitre is a comparatively recent disease. It was not present in the Americas or in New Zealand, ${ }^{55}, 55 a, 57$ or in Ceylon ${ }^{58}$ or in the Philippine Islands, ${ }^{59}$ or in most of Africa ${ }^{60}$ until after the coming of Europeans. As has been the case with so many other diseases, goitre has come and gone and, sometimes, come again. $55,55 \mathrm{a}, 56,61,62$

The history of goitre in country after country contradicts the hypothesis that the disorder is due to a lack of iodine. Critical examination of the evidence adduced in support of this hypothesis shows it to be of questionable value. ${ }^{63,64}$

Goitre is, I believe, an infectious disease-generally slowly developing but, occasionally, quite acute. In some respects, goitre resembles leprosy, in that transmission generally requires prolonged exposure. Sometimes, however, very short exposure is sufficient. Epidemics of goitre have occurred repeatedly. ${ }^{62}$ Laveran ${ }^{65}$ in his book on the diseases and epidemics of armies, gave 13 pages to epidemic goitre, almost as much as the 16 pages he devoted to syphilis, yellow fever or alcoholism. Epidemics of goitre are still being reported from 


\section{Notes on the History of Goitre in Sweden}

Italy and other places. For reviews, see Anglesio ${ }^{68}$ and Mortara ${ }^{67}$ The character of the endemicity of goitre, in particular its association with water-courses and, in many parts of the world, with rather deep and narrow valleys or other topographical features, ${ }^{1}$ may indicate the presence of a carrier, or of carriers, of rather limited range. In my opinion, the variety of the manifestations of goitre: simple euthyroid parenchymatous goitre, cretinism, thyrotoxicosis, etc., depends upon the reaction of different individuals, in different environments, to the same, or related, agent.

\section{Summary}

The history of goitre in Sweden is reviewed. It is concluded that the disorder appeared first at about 1800 in Falun and spread gradually and then more rapidly. Falun is no longer conspicuous for its goitres. In I93 $\mathrm{I}$, the prevalence there was less than in many other places in Sweden. It is suggested that goitre is an infectious disease introduced into Falun by German miners who were brought to Falun by Polhem late in the eighteenth century.

\section{REFERENCES}

1. Höjer, J. Axel, 'Strumaundersökningar', Nordisk Hygiensk Tidskrift, 1928, 1x, 61-125.

2. BuörnstÅnl, Jaco в Jonas. Resa til Frankrike, Italien, Sweitz, Tyskland, Holand Angland, Turkiet, och Grekeland, 6 vols. Stockholm, $1780-4$.

3. Palmstedt, Erik, Resedagbok $1778-1780$, Uppsala, 1927.

4. Svenska Akademien, Ordbok över Svenska Spräket, vol. vm, Lund, 1926.

5. HaARtman, Johann J., Tydelig underrättelse, om de mäst gängbara sjukdomars kännande och notande, genom lätta och enfaldiga hus-medel, etc., 2nd ed., Abo, 1765.

6. Acrel, Olof, Chirurgiske händelser änmärkte uti kongl. lazarettet, Stockholm, 759.

7. Acrel, Olof, Chirurgische Geschichte in königlichen Lazarette zu Stockholm angemerkt. Nach der zweyten . . . Ausgabe . . übersetzt von J. Andreas Murray, 2 vols. Göttingen, 1777.

8. IHRE, JOHANNE, Glossarum suiogothicum. . . U Uppsala, 1769.

9. Sahlstedt, Abraham, Svensk Ordbok met Latinisk Uttolkning, Stockholm, 773.

10. Widegren, Gustaf, Svensk och Engelsk Lexicon, Stockholm, i 788.

II. Widegren, Gustaf, Parallele des langues Frangoise-Suedoise ou dictionnaire Frangois et Suedois, 4 vols, Stockholm, 1795-1807. Swedish-French by Weste.

12. Blad h, G. E., Republiken Chile, Aren, 1821-1828, Stockholm, 1837.

13. Blad h, C. E., Resa till Montevideo och Buenos Ayres jemte beskrifning öfver Plata-Floden och de Förenta Provinserna af samma namn, Paraguay, Misiones och Republike oriental del Uruguay eller Cisplatina, Stockholm, 1839 .

14. KALM, PER, Wästgötha och Bohusländska Resa ar ${ }_{1742}$, Stockholm, 1746.

15. HÜl PHERs, ABR., Dagbok öfuer en Resa igenom. . . . Västerås, i 762.

16. HÜL P HERS, ABR., Samlingar till en beskrivning över Norrland, Västerås, 177 1-97.

17. HÅrleman, GarL, Dagbok öfver. . . . Resa en Stockholm, 1749.

18. Sundhets-Collegii Underdäniga berättelse om medicinal-verket i Riket, 1851, Första årgången, Stockholm, 1853 .

19. BergGren, A., 'Embetsberättelse för 1815', Svenska Läkare Sällskapets Handlingar III, 34,1816 .

20. Strömвом, Sixten, Porträttmáleren Lorens Pasch d.y. Stockholm, 1915. 


\section{Isidor Greenwald}

21. Berättelser till Ricksens Höglof. Ständer Röranda Medicinal Werkets Tillständ $i$ Riket. Ingifne wid Rigs-Dagen, I 769, af. Kongl. Collegio Medico. . . . Uppsala, I 769.

22. Drevon, translated William Radcliffe, A Journey through Sweden, etc., Dublin, I 790.

23. (Linnerholm, J. C.), Bref under resor $i$ Sverige. 3 vols. Kamblinski Tryckeriet, i 797, I806, I8I6.

24. Clarke, E. D., Travels in various countries of Europe, Asia and Africa. I I vols., London, 1824; Scandinavia in vols. 9, 10, 11 ; Falun in vol. 10.

25. Sснмidt, Johann Wilmel , Reise durch einige Schwedische Provinzen bis zu den südlichen Wohnplätzen der nomadischen Lappen, Hamburg, 1801.

26. Egk, Johann Georg, Reisen in Schweden, Leipzig, 1806.

27. Küttner, Gharles Gottlob, Travels through Denmark, Sweden, Austria and part of Italy in 1798 and 1799 , London, 1805 .

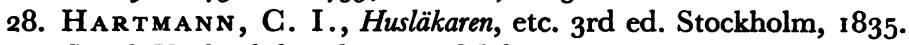

29. Svensk Upplagsbok, vol. xxvII, Malmö.

30. Sche NBe R g, Lexicon Latino-Svecanum, Norcopiae et Lincopia, 1747.

31. Be R G, Fr. TH., Bidrag till Sveriges medecinska topografi och statistik (Utdrag us årsberättelse till Kungl. Sundhets-Collegium för år 185 I), Stockholm, 1853 .

32. Hus, Ma gus. Om Sverige endemiska sjukdomar, Stockholm, 1852.

33. Statistika Central-Byran, Bidrag till sveriges officiela statistik, K. Helso-och Sjukvarden. I. Sundhets-Collegii underdäniga Berättelse. Ny följd.

34. Gras, O. 'Morbus Basedowii. Tachycardia. exophthalmica, strumosa', Uppsala läkareförenings förhandlingar, VII, 463-502, 1871-2; $1 \mathrm{x}, 38-75,1873-4$.

35. Hus, Magnus. 'Summarisk öfversigt af sjukvården å Kongl. Seraphimer-Lazaretts medico-cliniska afdelning under de sista 5 månarden af år 1839', Hygiea, II, 79-94, 1840.

36. Hus, MAGNus. 'Summarisk redogörelse för den cliniska undervissningen jemte sjukvarden å Kongl. Serafimer-Lazarettets afdelning för invärks sjuke, under loppet af år 1840', Hygiea, III, 49-66, 1841.

37. v. Döв L L N, J. W., 'Árs rapport fran. Kongl. Serafimer-Lazarettets kirurgiska afdelning för ar 1867,' Hygiea, xxx, 321-32, 1868.

38. von Friesen, FRedr. MAUR., 'Rapport öfver de vid Kongl. Serafimer-Lazarettets medecinska afdelning vardade sjuke och sjukdomar ar $1867^{\prime}$. Hygiea, $\mathrm{xxx}, 384-93,1868$.

39. Rossander, CARL J., 'Om urkratsning, évidement, af Struma', Hygiea, xxxvi, 66374, 1874 .

40. Rossander, Carl J., 'Évidement af Struma,' Hygiea, xxxvir, 601-5, 1875 .

41. Lindh, Alrik, 'Évidement af Struma', Hygiea, xL, 129-32, 1878.

42. Key, EINAR, 'Några kirurgiska minnen', Hygiea, c, Pt. I, 481-513, $193^{8}$.

43. Kock, Wolfram, Kungl. Serafimerlasarettet, 1752-1952. Thesis, Stockholm, 1952.

44. Frid, Gunnel, and Wijnbladh, HJalmar. 'Sub-acute Thyroiditis, Struma Lymphomatosa (Hashimoto's Disease) and Chronic Invasive Goitre (Riedel's Disease)', Acta chir. Scand., cxir, 1 70-85, 1957.

45. Wist R AND, A. T., Handbok $i$ Husmedecinen, $4^{\text {th }}$ ed. Stockholm, 1864 .

46. RUP P R I C T T, S., Dokt. S. Ruppricht's praktiska Husläkarebok, Stockholm, 1865.

47. Melander, A. F., Naturmedicin, Stockholm, 1867.

48. Hallin, Olof Fredr., 'Om struma i Falun', Hygiea, xxvir, 280-91, 1865.

49. HALliN, O. F., Helsan fran för allt. 2 vols., Stockholm, 1885.

50. Nauman, Gustav, Om Struma och dess behandling, Lund, 1891 .

51. Söderbaum, P., 'Om förekomsten af struma inom Gefleborgs och Stora Kapparbergs län på grund af undersökningar, gjorda af medlemmar af Gefleborgs-Dala Läkare-och apotekare förening', Hygiea, LV, II, 416- 18, 1893.

52. HöJer, J. Axel, Kropfstudien, V., 'Die Verbreitung des endemischen Kropfes in Schweden', Svenska Läkaresallskapets Handlingar, LvII, I-104, 193 I.

53. Hilde brand, Karl Gustav., Falu Stads Historia 1641-1687, Falun, 1946.

54. Lindroth, Sten, Christopher Polhem och Stora Kopparberget, Uppsala, I95I.

226 


\section{Notes on the History of Goitre in Sweden}

55. Greenwaid, I., 'The Early History of Goiter in the Americas, in New Zealand, and in England', Bull. Hist. Med., XVII, 229-68, 1945.

55a. Greenwald, I., 'The History of Goiter in the Inca Empire, Peru, Chile and the Argentine Republic', Texas Rep. Biol. Med., xv, 874-9, 1957.

56. GREENWALD, I., 'Observations on the History of Goiter in Ohio and in West Virginia', J. Hist. Med., X, 277-89, 1955 .

57. GREENWALD, I., 'Was Goitre present in New Zealand before the coming of Europeans?' 7. Hist. Med., XII, 72-4, 1957.

58. Greenwald, I., 'Some Notes on the History of Goitre in Ceylon', Ceylon Med. F., II, I40-I, 1953 .

59. Greenwald, I., 'The History of Goitre in the Philippine Islands', Bull. Hist. Med., XXvi, 263-8, 1951.

6o. Greenwald, I., 'The History of Goitre in Africa'; Bull Hist. Med., xxm, 155-85, 1949.

61. Krueger, E., and Armattor, R. E. G., 'Fifty Years in the Changing Panorama of Disease in West Africa, 1898-1948, Med. World (Lond.), LXxiv, 70-7, 1951.

62. Hirsch, A., Handbook of Geographical and Historical Pathology, vol. II, London, 1855.

63. Greenwald, I., 'Is Endemic Goitre Due to a Lack of Iodine?' 7. Clin. Endocr., vi, 708-41, 1946.

64. GreenWALD, I., 'The Human Requirement for Iodine'. Amer. F. Clin. Nutr., m, 215-24, 1955.

65. Laver an, A., Traité des maladies et des épidémies des armées, Paris, 1875.

66. Anglesio, E., Il gozzo acuto, Torino, 194 I.

67. Mortara, M., 'Il gozzo acuto nel quadro del gozzismo endemico', 1957, Tireopatie, V, 6I-140. 